\title{
Properties of Alluvial Soils of Taiga Forest under Anthropogenic Salinisation
}

\author{
Elena Khayrulina ${ }^{1, *(\mathbb{D}, \text { Anna Bogush }}{ }^{2}$, Larisa Novoselova ${ }^{1}$ and Natalya Mitrakova ${ }^{1}$ \\ 1 Institute of Natural Science, Perm State National Research University, 4 Genkel st., 614990 Perm, Russia; \\ Novoselova@psu.ru (L.N.); mitrakovanatalya@mail.ru (N.M.) \\ 2 Research Centre for Agroecology, Water and Resilience, Coventry University, \\ Ryton-on-Dunsmore CV8 3LG, UK; annakhol@gmail.com \\ * Correspondence: khayrulina@psu.ru
}

check for updates

Citation: Khayrulina, E.; Bogush, A.; Novoselova, L.; Mitrakova, N. Properties of Alluvial Soils of Taiga Forest under Anthropogenic Salinisation. Forests 2021, 12, 321. https://doi.org/10.3390/f12030321

Received: 1 February 2021

Accepted: 3 March 2021

Published: 10 March 2021

Publisher's Note: MDPI stays neutral with regard to jurisdictional claims in published maps and institutional affiliations.

Copyright: (c) 2021 by the authors. Licensee MDPI, Basel, Switzerland. This article is an open access article distributed under the terms and conditions of the Creative Commons Attribution (CC BY) license (https:// creativecommons.org/licenses/by/ $4.0 /)$.

\begin{abstract}
The environmental impact of deposit development can be indirect and can cause combined geochemical processes in ecosystems. These must be taken into consideration under environmental forecasting and environmental risk assessment. Soil degradation in the Taiga Forest is considered, within the area of Verkhnekamskoye potash deposit (Russia), as an example of such environmental transformation. Here, the mechanism and characteristics of the anthropogenic salinisation of alluvial soils under potash deposit development are newly described. It was found that there is a strong anthropogenic impact of the potash industry on valley soils where the contaminated $\mathrm{Na}-\mathrm{Cl}$ groundwater discharges or is close to the surface. The valley soils are characterised by high salinity, and the sum of toxic salts in soils has reached $26 \%$. Alluvial gley humic clay chloride saline soil (Gleyic Fluvisols (Salic, Loamic, Technic)) and secondary solonchak on alluvial humic clay soil sulphate-chloride gypsum-containing surface-gleyed (Chloridic Gleyic Fluvic Solonchak (Hypersalic, Loamic, Technic)) were formed in hydromorphic conditions. Morphological, physicochemical and mineralogical analyses were carried out. Under hydromorphic conditions, Chloridic Gleyic Fluvic Solonchak (Hypersalic, Loamic) was described to show a hydrotroillite layer and reddish-yellow iron-rich precipitates on its surface. The top soil horizon has the highest content of iron minerals (up to $84.9 \%$ ) and Fe-bearing plant residues (up to $20 \%$ ). Additionally, the spongy and gel-like organic materials, as well as the siliceous remains of diatoms, are enriched in $\mathrm{Ca}, \mathrm{Fe}, \mathrm{Cl}, \mathrm{K}, \mathrm{Na}$, S and $\mathrm{P}$. The lower soil horizon consists of black gel-like phases and hydrogen sulphide settings with a high content of plant residues. The insoluble part of the samples contains up to $84 \%$ hydrogoethite. The sources of iron in soils and bottom sediments include the iron-enriched Sheshma sediments speckled rocks, slurry material, halite wastes and soil minerals of alluvial gley soils.
\end{abstract}

Keywords: potash mining; soil salinity; sulfidisation process; Fe-bearing minerals; leaching; ion exchange processes

\section{Introduction}

Environmental risk assessments of potash mining usually describe the anthropogenic salinisation of groundwater and surface water. The problems of brine distribution in groundwater and surface water were researched by reference [1,2] in Germany, reference [3] and reference [4] in Russia. These studies discovered saline drainage filtrations of slurry storage facilities and salt tailing piles into ground water and discharges of saline groundwater into local river valleys.

The interaction of saline drainages with rocks was studied by reference [5] in the Verkhnekamskoe potash deposit in Russia and reference [6] in the Upper Rhine Valley in France.

The analysis of soil salinisation is usually combined with vegetation research. Hulisz and Piernik [7] found very high and stable soil salinity values by analysing the electrical 
conductivity, as well as the main anion and cation contents in an area affected by post-soda waste. They stated that soil salinisation was linked to the level of saline ground water and some species of halophytes could be indicators of soil salinity. Sommer et al. [8] also analysed electrical conductivity, as well as main anion and cation contents in soils in order to describe the holophilic algal communities near potash tailing piles in the Lower Saxony and Saxony-Anhalt regions (Germany). The general environmental issues related to the potash industry in Belorussia-including soil salinisation-were described by G.A. Kolpashnikov et al. [9] and V.S. Khomich et al. [10].

However, an increase in salt content in soils, groundwater and surface waters can cause different geochemical processes associated with water-rock interactions, such as element leaching, ion exchange, secondary mineral formation, etc. These processes have been described in arid ecosystems. For example, accumulation of iron-bearing minerals in soils in seepage areas and hydrogen sulphide settings in soil were generally described by A.I. Perel'man and N.S. Kasimov [11] in the Caspian lowland, and by R. Fitzpatrick el al. [12] and R.B. Salama et al. [13] in Australia.

The transformation of geochemical processes during anthropogenic soil salinisation was researched by V.S. Khomich [14]. Via a landscape-geochemical analysis near a slurry storage facility in Belorussia, V.S. Khomich described the appearance of hydrotroillite at a soil depth of $45-90 \mathrm{~cm}$ as a result of $\mathrm{SO}_{4}{ }^{2-}-\mathrm{Na}^{+}$drainage pollution.

We predict that soil salinisation in areas affected by the potash industry is a result of the complex interactions of waste, drainage water, groundwater, rocks and soils, which not only causes an increase in the content of salts, but also other elements, in addition to the formation of new soil conditions.

Research into geochemical processes was carried out in the territory of the Verkhnekamskoe potash deposit in Russia (Figure 1), where soil salinisation occurs due to the influence of potash mining. Soil salinisation has been identified in the area that is affected by the sludge storage and salt dumps of the Verkhnekamskoe potash deposit, and bare soils have acquired reddish-yellow iron-rich precipitates on their surface [15]. The presence of brines in the slurry storage facility and salt tailing piles represents the most serious environmental issue in potash mining regions.

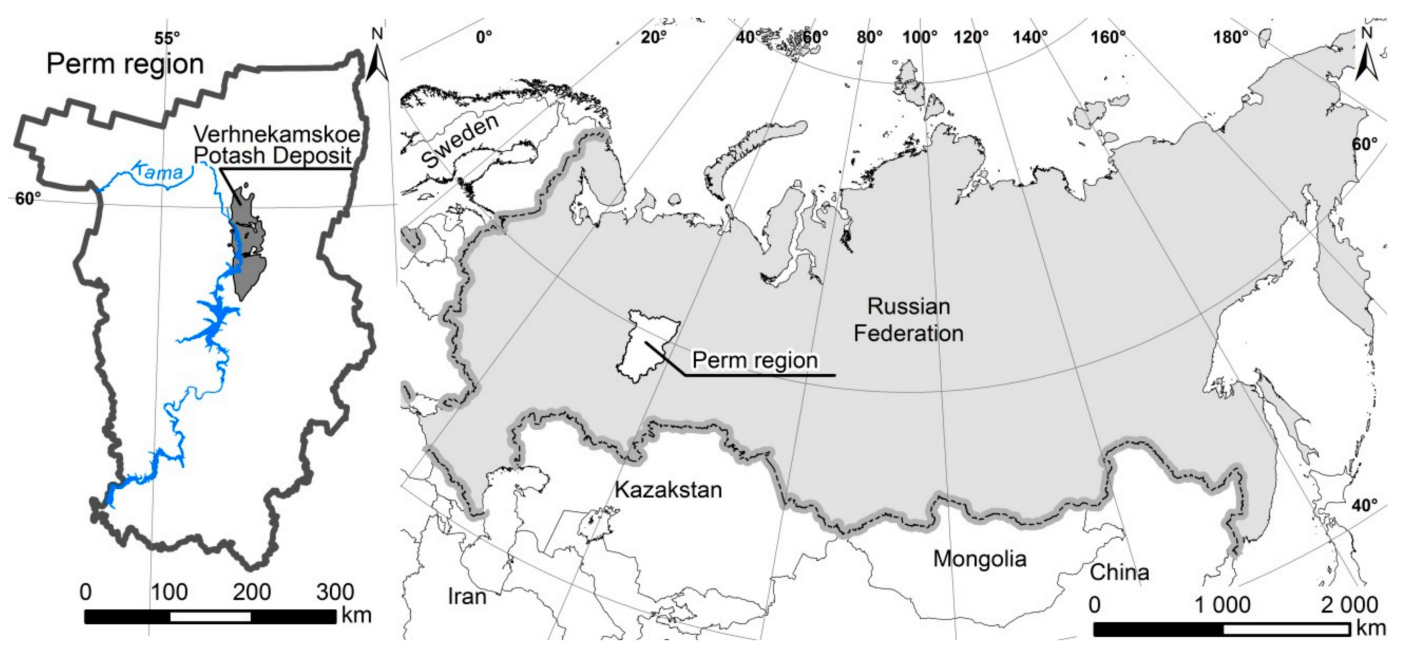

Figure 1. Geographical location of the Verkhnekamskoe potash deposit.

The main goal of this study is to identify the physicochemical properties of saline soils and mineral formation and to describe the main causes of iron leaching from rocks and soils and hydrogen sulphide settings in the Taiga Forest. The study focuses on two types of soils that were observed in the Lyonva River valley, with different salt contents. Based on field observations, in addition to geochemical and mineralogical analyses, we hypothesised that saline ground water not only causes soil salinisation, but also causes 
iron leaching from rocks and soils, iron mineral accumulation on the surface of soil, and hydrogen sulphide deposition in soil.

\section{Materials and Methods}

\subsection{Site Description}

The Verkhnekamskoe potash deposit is located on the left bank of the Kama River in Russia and has an area of about $6.5 \times 103 \mathrm{~km}^{2}$ (Figure 1). The ore contains between 18 to $34 \% \mathrm{KCl}$ [16]. The geological reserve of carnallite is about 96.4 billion tons, sylvinite112.2 billion tons, halite- 4.65 trillion tons. Annual production of potassium-magnesium salts is about 40 million tons.

The Verkhnekamskoe potash deposit has solid (more than $500 \mathrm{~m}$ in depth) salt strata with layers (from bottom to top) of underlying rock salt (URS) (320-400 m), potash deposits $(70-100 \mathrm{~m})$ and covering rock salts (CRS) $(20 \mathrm{~m})$. The salt stratum is underlain by clay-anhydrite deposits (200-220 m) and covered with salt-marl (SMS) and terrigenouscarbonate (TCS). A set of salts is related to the Iren horizon of the Kungurian strata of the lower Permian System [17]. The lens-shaped salt strata of the deposit acts as a regional aquiclude, dividing the supersalt and subsalt waters [17].

Active water exchange occurs in the upper part of supra-salt strata. The speckled (SS) and quaternary $(\mathrm{Q})$ deposits are particularly vulnerable to potash mining activities [18].

The main source of the environmental pollution in this mining area is uncontrolled discharge of drainage waters of salt tailing piles and salt-clay slurry storage, which were constructed 50-90 years ago. Currently, more than 270 million tons of halite waste and 30 million $\mathrm{m}^{3}$ of salt-clay slime have accumulated in the territory of the Verkhnekamskoye potash deposit [19]. Halite waste with over $90 \% \mathrm{NaCl}$ is typically placed in piles, while clay slimes and brines drain into storage facilities (Figure 2). Clay-salt slurry contains $35-40 \%$ water-soluble salts and $60-65 \%$ insoluble clay materials. Brines have a $\mathrm{Na}-\mathrm{Cl}$ composition and more than $300 \mathrm{~g} / \mathrm{L}$ of total dissolved solids (TDS) [19]. The territory of the Verkhnekamskoe potash deposit is affected by seven potash mines (Figure 3).
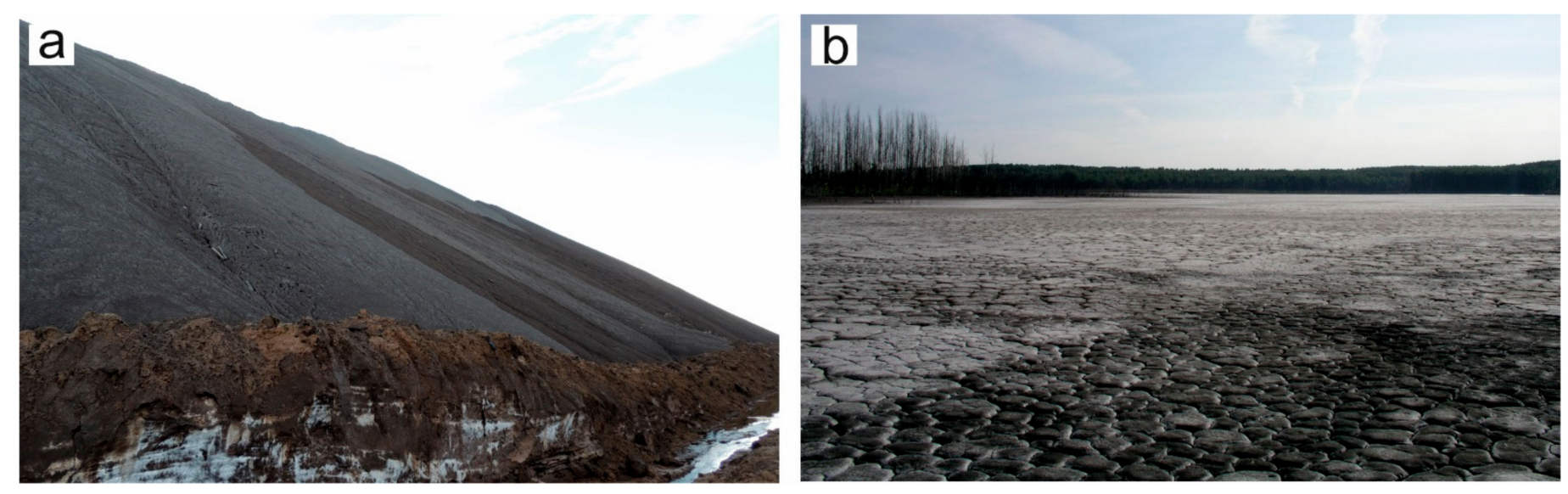

Figure 2. Potash waste storages: (a) slurry storage facility; (b) salt tailing pile with drainages.

Our studies were carried out in the territory of the Verkhnekamskoe potash deposit in the Lyonva River valley which has two potash mines, slurry storage facilities and salt tailings pile in the Lyonva catchment area. Subsidence processes and karst sinkhole formation have occurred as a result of mining activities in this area [20].

The Lyonva River valley is represented by quaternary sediments (fine alluvial-deluvial sands, loam, eluvial-deluvial clay, gruss-rock and coarse medium gravels) and Permian systems (interlaid siltstones and sandstones). The groundwater of quaternary sediments is found at a depth of $0.0-3.0 \mathrm{~m}$ in the Lyonva River valley. The groundwater and surface water are freshwater sources with a salinities of $0.23-0.50 \mathrm{~g} / \mathrm{L}$ and a calcium-carbonate 
composition (prior to mining activities). In the river valleys, according to the Russian soil classification [21], the soils are classified as alluvial grey humic gley [21].

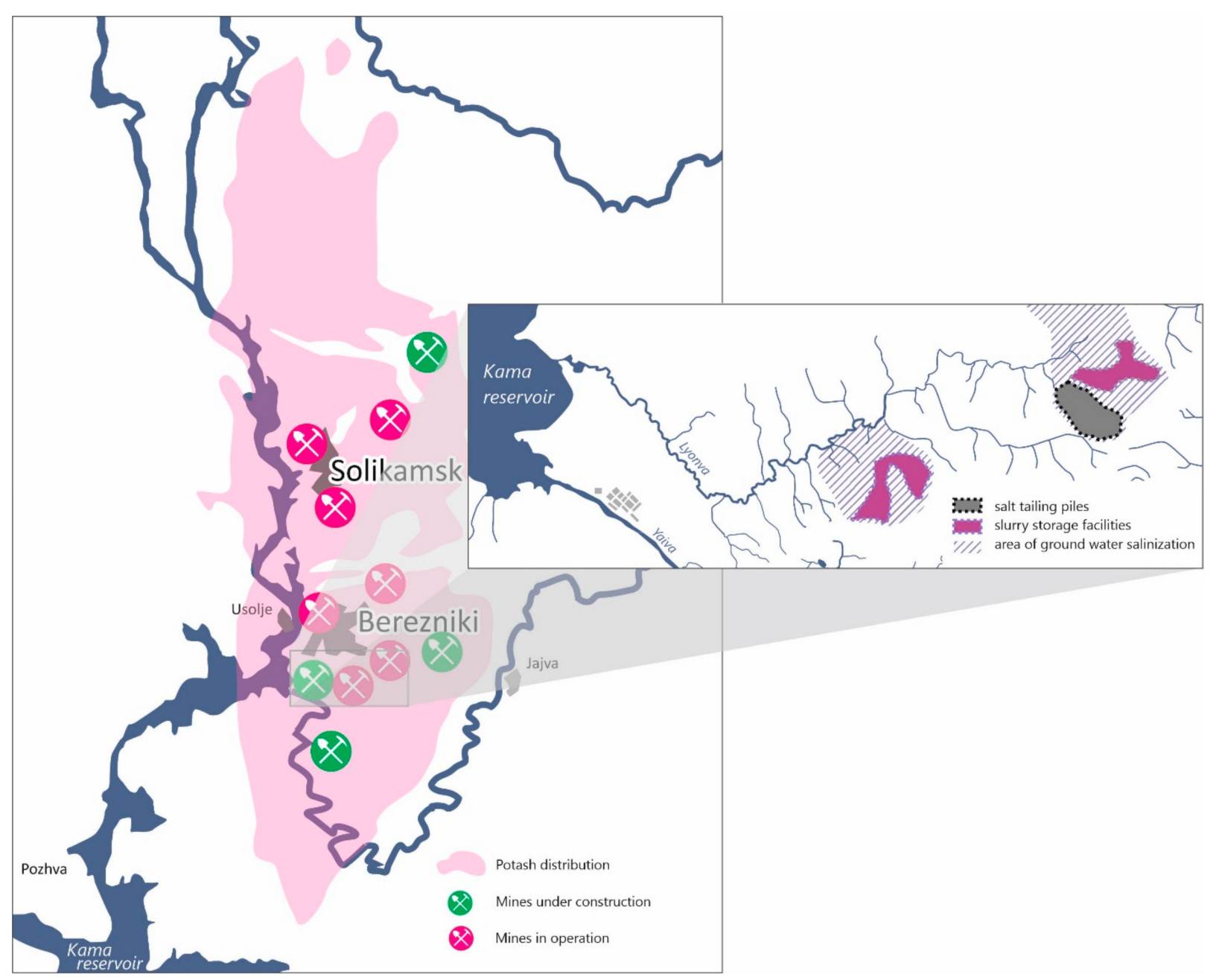

Figure 3. Scheme of the Verkhnekamskoe Potash deposit and research territory.

\subsection{Sampling Procedures}

Ecosystem degradation due to potash mining was studied during 2013-2016 in the southern part of the Verkhnekamskoe potash deposit. Observations of alluvial soils and their degradations were carried out [22]. For more detailed study, we selected two types of alluvial soils from the Lyonva River valley that represent different influences of saline groundwater.

The soil samples were collected at depths of $0-3 \mathrm{~cm}$ (4 samples) and 3-30 cm ( $3 \mathrm{sam}$ ples) according to the different horizons and in 2 soil profiles in the Lyonva River valley in July 2016 (Figures 4 and 5). Soil samples were collected and stored in plastic bags.

Sampling of infiltration through the dam of the slurry storage facility was carried out to investigate the chemical composition of drainage water of potash mining wastes. The Lyonva River was studied at $1 \mathrm{~km}$ (18 samples) downstream from the slurry storage facility (Figure 4). Water from two springs (11 samples) was taken in the Lyonva River valley (Figure 4) to assess groundwater pollution and its role in soil salinisation (Figure 4). Samples of surface waters and springs were collected four times a year in plastic bottles during periods of low-water levels in December and July and high-water levels in May and October. Additionally, water samples were collected for $\mathrm{Fe}_{t}$ analysis. Water samples for analysis of elemental composition were filtered, acidified with pure $\mathrm{HCl}$ and stored in a refrigerator. 


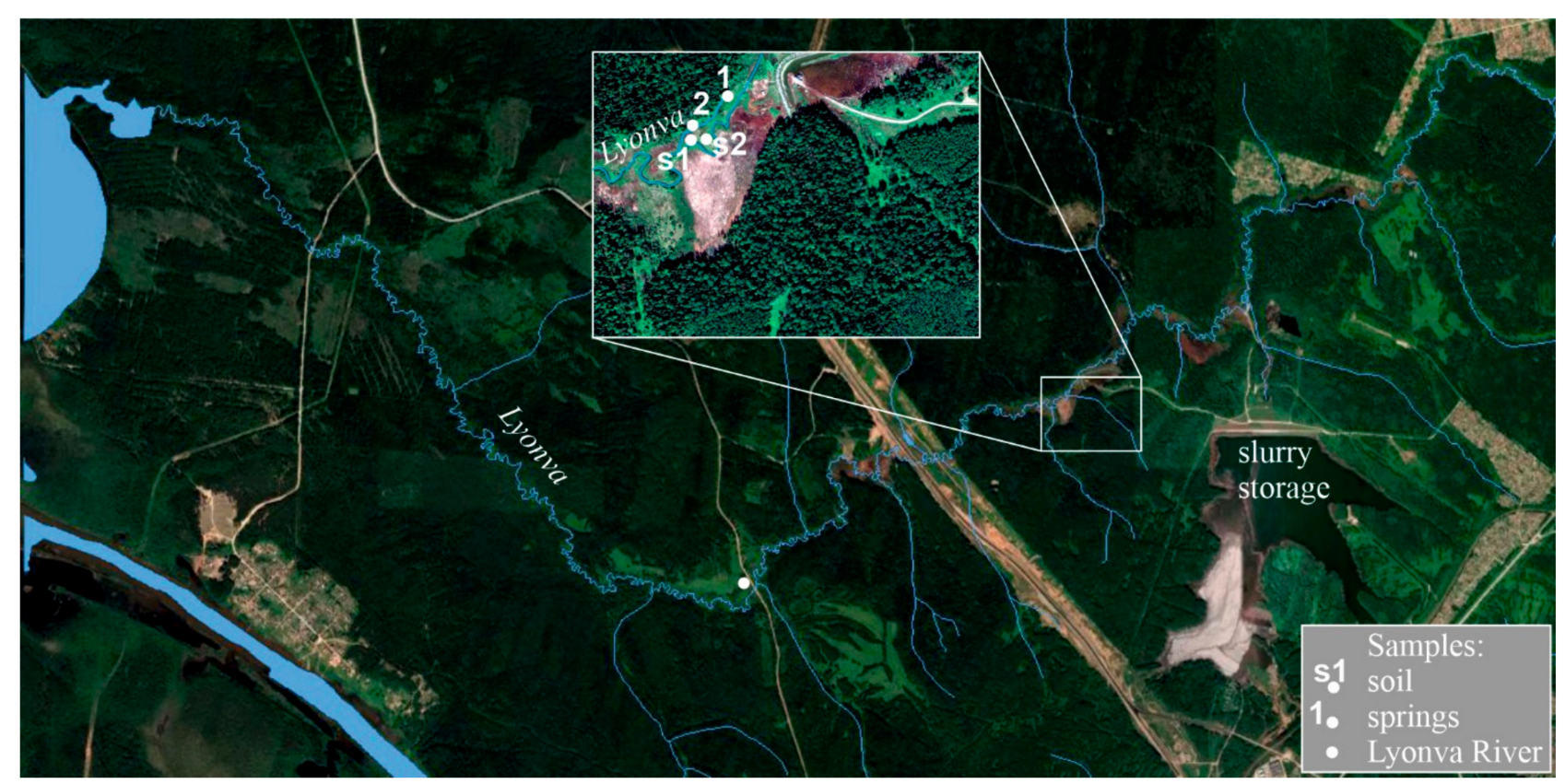

Figure 4. Locations of water and soil sampling sites.
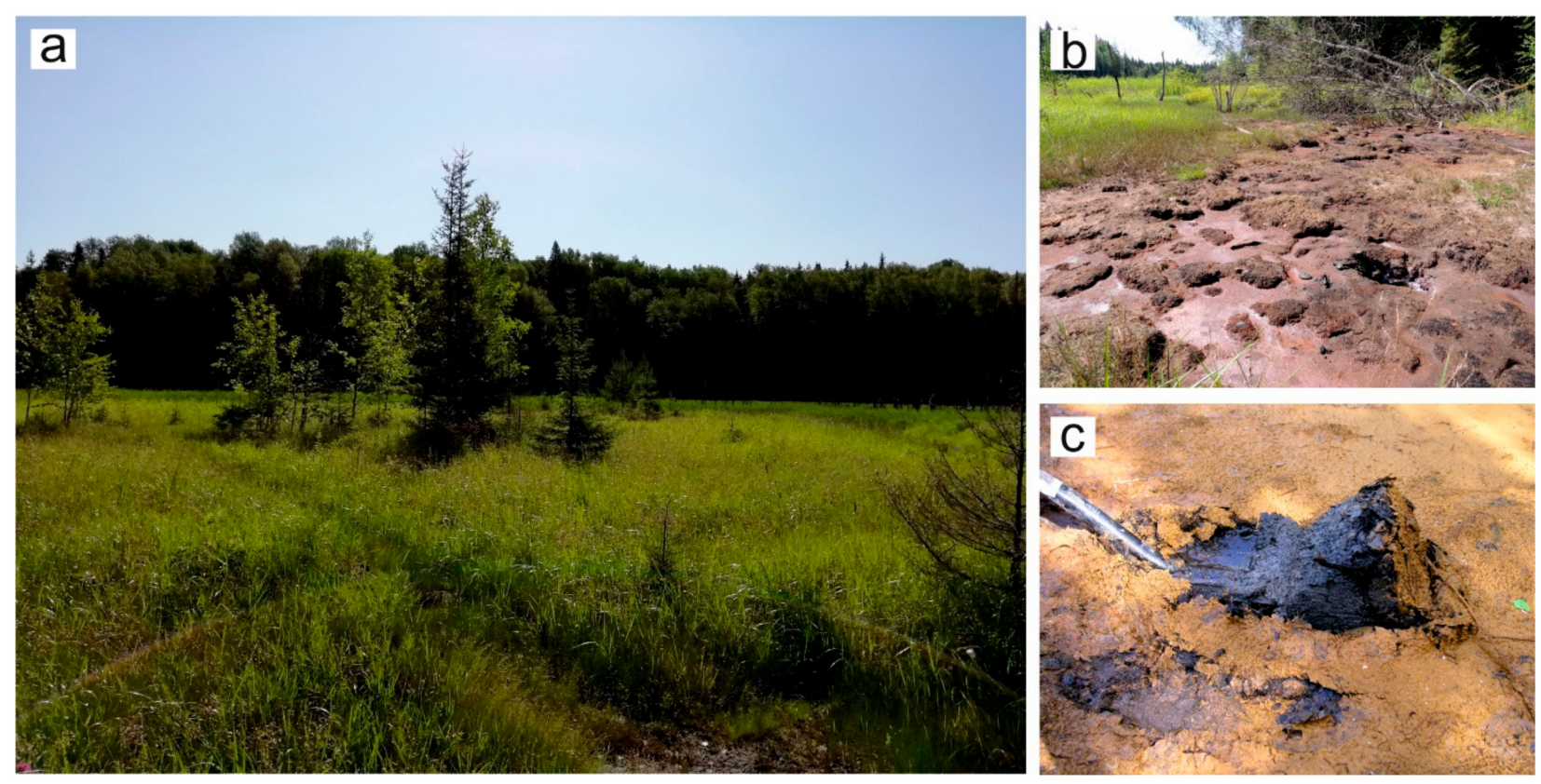

Figure 5. Soil sampling sites: (a) Gleyic Fluvisols (Salic, Loamic); (b) Chloridic Gleyic Fluvic Solonchak (Hypersalic, Loamic); (c) iron-bearing crust on the surface of the soil and black gel-like phases in lower sulphide horizon of Chloridic Gleyic Fluvic Solonchak (Hypersalic, Loamic).

\subsection{Analytical Procedures}

Morphological and physicochemical methods were used to assess the ecological state of the soils. Morphological analysis was carried out according to the "Classification and Diagnosis of Soils of Russia" [21].

The soil samples had been air-dried at room temperature for two weeks, then crushed and sieved through a $2 \mathrm{~mm}$ screen. This fraction was used for the physicochemical analysis of soils. Soil $\mathrm{pH}$ was analysed by a $\mathrm{pH}$-meter [23]. Soil organic matter was determined by the wet-combustion Tyurin method [24]. Soil hydrolytic acidity was determined by the Kappen method, based on treating the soil sample with sodium acetate at a concentration 
of $1 \mathrm{~mol} / \mathrm{L}$, followed by titration of soil extract with alkaline solution. Exchangeable cations were determined by the Kappen-Gilkowitz method, which is a treatment of soil samples with a certain amount of $0.1 \mathrm{~N} \mathrm{HCl}$, followed by titration of soil extracts with $0.1 \mathrm{~N}$ $\mathrm{NaOH}$ [23]. The cation exchange capacity (CEC) in carbonate samples was determined by the barium chloride method [24]. Mobile phosphates and potassium were determined by the Kirsanov method [24] based on the extraction of mobile phosphates and potassium from the soil with a solution of $0.2 \mathrm{M} \mathrm{HCl}$. Then mobile phosphates were determined as a blue phosphorus-molybdenum complex on a photoelectrocolorimeter and potassium on a flame photometer [25]. Soluble salts were determined in water extractions of soil samples, followed by determination of anions and cations. Carbonates were determined by back-titration with sulphuric acid. The $\mathrm{Na}^{+}$concentrations in water extraction were analysed by flame photometer and concentrations of $\mathrm{Ca}^{2+}$ and $\mathrm{Mg}^{2+}$ were analysed by the titration method with Trilon B (disodium dihydrogen ethylenediaminetetraacetate), and sulphate ions were calculated as the difference between the amounts of cations and anions [24]. $\mathrm{H}_{2} \mathrm{~S}$ was analysed by the titration method which is based on the oxidation of $\mathrm{H}_{2} \mathrm{~S}$ with iodine released during the interaction of potassium iodide with $\mathrm{KMnO}_{4}$ [26].

Samples of groundwater and surface water were analysed for $\mathrm{NO}_{2}{ }^{-}, \mathrm{NO}_{3}{ }^{-}, \mathrm{NH}_{4}{ }^{+}$, $\mathrm{Cl}^{-}, \mathrm{K}^{+}, \mathrm{SO}_{4}{ }^{2-}, \mathrm{Ca}^{2+}, \mathrm{Na}^{+}, \mathrm{Mg}^{2+}$ by capillary electrophoresis Kapel-104. The $\mathrm{pH}$ of the aqueous extract and the $\mathrm{HCO}_{3}{ }^{-}$and TDS contents were determined by titration [25].

The soil samples were pretreated by removal of less than $0.01 \mathrm{~mm}$ clay fractions with wet preparation. Soil mineralogy was then determined by using a Nikon 104 binocular microscope and XRD using a D2 Phaser desktop diffractometer "Bruker" at the Center for collective use at Perm State National Research University.

The morphology and microstructure of the samples were investigated using a TESCAN MIRA 3 LMU and LEO 1430VP high-performance, variable pressure, analytical scanning electron microscope (SEM). Energy-dispersive X-ray spectroscopy (EDS; Oxford Instrument X-Max 80 EDS-system) was used for microanalysis of the solid phases viewed by SEM. Microphotography of the sand-aleurite part of a number of samples was carried out using a Leica-MZ-16 microscope.

\subsection{Soil Salinity Estimation}

The estimation of soil salinity was based on calculating the levels of toxic and non-toxic salts, taking into account the binding of ions in a certain sequence to hypothetical salts, starting with less soluble salts and ending with more soluble ones. First of all, cations and anions of carbonates bind in the following order $\mathrm{Na}_{2} \mathrm{CO}_{3}, \mathrm{MgCO}_{3}, \mathrm{Ca}\left(\mathrm{HCO}_{3}\right)_{2}, \mathrm{NaHCO}_{3}$, $\mathrm{Mg}(\mathrm{HCO})_{2}$; next, with $\mathrm{SO}_{4}{ }^{2-}$ anions in the sequence: $\mathrm{CaSO}_{4}, \mathrm{Na}_{2} \mathrm{SO}_{4}, \mathrm{MgSO}_{4} ;$ last $\mathrm{Cl}^{-}$: $\mathrm{NaCl}, \mathrm{MgCl}_{2}, \mathrm{CaCl}_{2}$ [27].

The toxicity threshold is the limiting amount of salts in the soil, above which inhibition of the growth and development of salt resistant plants begins. Toxicity thresholds for individual ions: (mEq/100 $\mathrm{g}$ of soil) $\mathrm{CO}_{3}{ }^{2-}-0.03 ; \mathrm{HCO}_{3}{ }^{-}-0.8 ; \mathrm{Cl}^{-}-0.3 ; \mathrm{SO}_{4}{ }^{2-}-1.7$ [28]. We used the sodium adsorption ratio (SAR) [29] to determine sodium soils which may be an alternative to the exchangeable sodium percentage of the cation exchange capacity (CEC).

\section{Results and Discussion}

The rainfall level in the area of the Verkhnekamskoe potash deposit is around $650 \mathrm{~mm} / \mathrm{year}$ and the average temperature is $0{ }^{\circ} \mathrm{C}$. This climatic condition promotes formation of a clay-salt slurry and halite waste drainage water that discharges into the groundwater. A change in the groundwater composition from $\mathrm{Ca}-\mathrm{HCO}_{3}$ to $\mathrm{Na}-\mathrm{Cl}$ was observed in close proximity to the slurry storage facility. The highest level of salinisation was detected in the groundwater from quaternary (Q) sediments (up to $26.1 \mathrm{~g} \mathrm{~L}^{-1}$ of $\mathrm{Cl}$ ) [15]. This aquifer was the most affected by potash mining activities. A part of the drainage water enters into the speckled $\left(\mathrm{P}_{1} \mathrm{ss}\right)$ aquifers, increasing the $\mathrm{Cl}$ content in the groundwater up to $5.3 \mathrm{~g} \mathrm{~L}^{-1}$ [15].

The discharge of contaminated groundwater as springs, as well as areal, subaqueous and surface discharge of high salinity waters in the Lyonva River valley (Figure 6), leads to 
the salinisation of previously fresh river and valley water. The water of the Lyonva River has a sodium-chloride composition, neutral $\mathrm{pH}$, and concentrations of $\mathrm{Cl}^{-}, \mathrm{SO}_{4}{ }^{2-}, \mathrm{Ca}^{2+}$, $\mathrm{Mg}^{2+}, \mathrm{Na}^{+}, \mathrm{K}^{+}, \mathrm{Fe}_{\mathrm{t}}$ (Table 1).

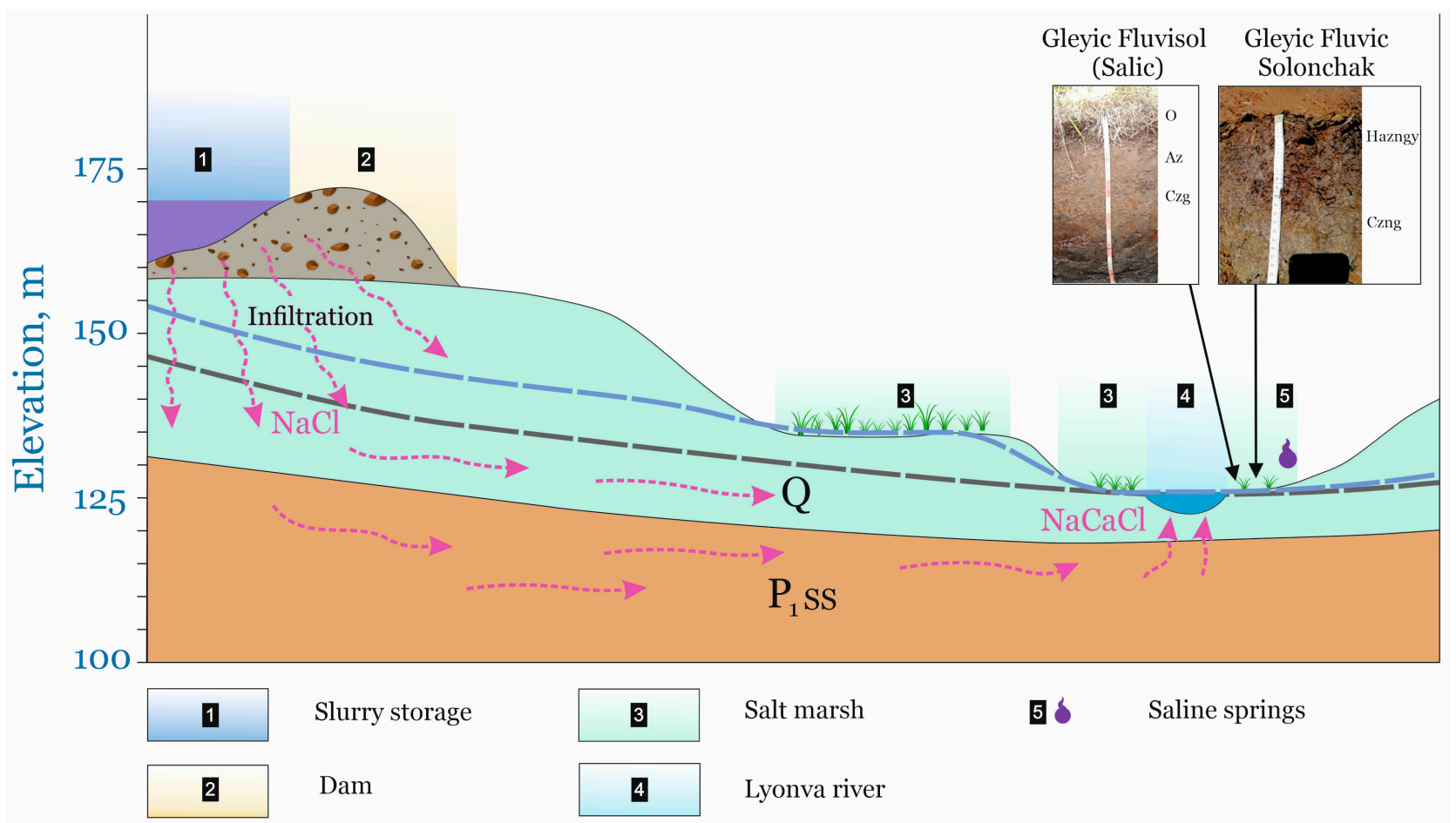

Ground water level before construction

Ground water level after construction

Figure 6. Cross section of the Lyonva River valley illustrating the multi-process formation of saline soils.

Table 1. Water chemistry in the vicinity of the slurry storage site [15].

\begin{tabular}{|c|c|c|c|c|c|}
\hline Components & $\begin{array}{l}\text { Infiltration through } \\
\text { the Dam of Slurry } \\
\text { Storage Site }\end{array}$ & $\begin{array}{l}\text { Saline Spring }(Q) \text { in the } \\
\text { Lyonva River Valley }\end{array}$ & $\begin{array}{l}\text { Saline Spring (P1ss) in } \\
\text { the Lyonva River Valley }\end{array}$ & $\begin{array}{l}\text { The Lyonva River } 1 \mathrm{~km} \\
\text { from the Slurry Storage } \\
\text { Site Downstream }\end{array}$ & MAC \\
\hline $\mathrm{pH}$ & $\begin{array}{c}6.9^{*} \\
6.3-7.2 * *\end{array}$ & $\begin{array}{c}6.9 \\
6.8-7.0\end{array}$ & $\begin{array}{c}7.1 \\
7.0-7.1\end{array}$ & $\begin{array}{c}7.2 \\
6.8-7.7\end{array}$ & $6.5-8.5$ \\
\hline $\mathrm{HCO}_{3}{ }^{-}(\mathrm{mg} / \mathrm{L})$ & $\begin{array}{c}341 \\
293-458\end{array}$ & $\begin{array}{c}153 \\
11.0-186\end{array}$ & $\begin{array}{c}129 \\
99-148\end{array}$ & $\begin{array}{c}137 \\
99-174\end{array}$ & \\
\hline $\mathrm{SO}_{4}{ }^{2-}(\mathrm{mg} / \mathrm{L})$ & $\begin{array}{c}1830 \\
646-4190\end{array}$ & $\begin{array}{c}374 \\
191-598\end{array}$ & $\begin{array}{c}106 \\
84-122\end{array}$ & $\begin{array}{c}600 \\
73-1793\end{array}$ & 100 \\
\hline $\mathrm{Cl}^{-}(\mathrm{mg} / \mathrm{L})$ & $\begin{array}{c}33.400 \\
5540-66.700\end{array}$ & $\begin{array}{c}15.000 \\
6950-26.200\end{array}$ & $\begin{array}{c}3210 \\
2370-5310\end{array}$ & $\begin{array}{c}7931 \\
3320-15.290\end{array}$ & 300 \\
\hline $\mathrm{NO}_{2}^{-}(\mathrm{mg} / \mathrm{L})$ & $\begin{array}{c}6.1 \\
0.34-10.3\end{array}$ & $<0.2$ & $<0.2$ & $\begin{array}{c}3.3 \\
0.1-12.3\end{array}$ & 0.08 \\
\hline $\mathrm{NO}_{3}{ }^{-}(\mathrm{mg} / \mathrm{L})$ & $\begin{array}{c}78.0 \\
15.0-127\end{array}$ & $\begin{array}{c}27.2 \\
0.2-65.0\end{array}$ & $\begin{array}{c}25.4 \\
10.8-62.0\end{array}$ & $\begin{array}{c}15.7 \\
2.8-32.4\end{array}$ & 40 \\
\hline $\mathrm{Ca}^{2+}(\mathrm{mg} / \mathrm{L})$ & $\begin{array}{c}1530 \\
721-2710\end{array}$ & $\begin{array}{c}1240 \\
552-2170\end{array}$ & $\begin{array}{c}418 \\
275-627\end{array}$ & $\begin{array}{c}1179 \\
561-1593\end{array}$ & 180 \\
\hline $\mathrm{Mg}^{2+}(\mathrm{mg} / \mathrm{L})$ & $\begin{array}{c}270 \\
146-727\end{array}$ & $\begin{array}{c}947 \\
117-5190\end{array}$ & $\begin{array}{c}76 \\
49-116\end{array}$ & $\begin{array}{c}281 \\
122-383\end{array}$ & 40 \\
\hline $\mathrm{Na}^{+}(\mathrm{mg} / \mathrm{L})$ & $\begin{array}{c}16.700 \\
7060-32.100\end{array}$ & $\begin{array}{c}6400 \\
2560-11.000\end{array}$ & $\begin{array}{c}1200 \\
866-1920\end{array}$ & $\begin{array}{c}3083 \\
781-6422\end{array}$ & 120 \\
\hline
\end{tabular}


Table 1. Cont.

\begin{tabular}{|c|c|c|c|c|c|}
\hline Components & $\begin{array}{l}\text { Infiltration through } \\
\text { the Dam of Slurry } \\
\text { Storage Site }\end{array}$ & $\begin{array}{l}\text { Saline Spring }(Q) \text { in the } \\
\text { Lyonva River Valley }\end{array}$ & $\begin{array}{l}\text { Saline Spring (P1ss) in } \\
\text { the Lyonva River Valley }\end{array}$ & $\begin{array}{l}\text { The Lyonva River } 1 \mathrm{~km} \\
\text { from the Slurry Storage } \\
\text { Site Downstream }\end{array}$ & MAC \\
\hline $\mathrm{K}^{+}(\mathrm{mg} / \mathrm{L})$ & $\begin{array}{c}10,800 \\
5170-23.700\end{array}$ & $\begin{array}{c}3230 \\
1230-5860\end{array}$ & $\begin{array}{c}489 \\
339-894\end{array}$ & $\begin{array}{c}1259 \\
158-4237\end{array}$ & 50 \\
\hline $\mathrm{Fe}_{\mathrm{t}}(\mathrm{mg} / \mathrm{L})$ & $\begin{array}{c}0.5 \\
0.14-0.98\end{array}$ & $\begin{array}{c}0.6 \\
0.11-1.38\end{array}$ & $\begin{array}{c}0.8 \\
0.46-1.38\end{array}$ & $\begin{array}{c}0.8 \\
0.6-0.9\end{array}$ & 0.1 \\
\hline $\mathrm{NH}_{4}{ }^{+}(\mathrm{mg} / \mathrm{L})$ & $\begin{array}{c}53.0 \\
5.0-193\end{array}$ & $\begin{array}{c}16.2 \\
15.3-17.0\end{array}$ & $<0.5$ & $\begin{array}{c}23.1 \\
0.6-93.5\end{array}$ & 0.5 \\
\hline TDS (mg/L) & $\begin{array}{c}45.000 \\
11.600-77.200\end{array}$ & $\begin{array}{c}29,400 \\
11.700-46.100\end{array}$ & $\begin{array}{c}5950 \\
4570-9540\end{array}$ & $\begin{array}{c}12,888 \\
5294-21.840\end{array}$ & 1000 \\
\hline $\begin{array}{l}\text { Number of } \\
\text { samples }\end{array}$ & 10 & 7 & 4 & 18 & \\
\hline
\end{tabular}

Note: MAC — maximum allowable concentration; ${ }^{*}$-average; ${ }^{* *}$-minimum and maximum values.

The drainage waters entering into the groundwater formed a large saline plume between the storage facility and the river channel. The background groundwater belongs mainly to the $\mathrm{Ca}-\mathrm{HCO}_{3}$ water type, in some cases under contact with gypsum-to the $\mathrm{Ca}-\mathrm{SO}_{4}$ type [17]. The drainage waters from the dam of slurry storage site affects the groundwater composition: $\mathrm{Na}-\mathrm{Cl}$ water type, high concentrations of $\mathrm{K}^{+}\left(5.85 \mathrm{~g} \mathrm{~L}^{-1}\right)$, $\mathrm{SO}_{4}{ }^{2-}\left(0.59 \mathrm{~g} \mathrm{~L}^{-1}\right)$ and $\mathrm{Mg}^{2+}\left(5.18 \mathrm{~g} \mathrm{~L}^{-1}\right)$ (Table 1$)$.

Another indicator of pollution is the high content of nitrogen compounds in drainage water, groundwater and surface water (Figure 7). The $\mathrm{NH}_{4}{ }^{+}, \mathrm{NO}_{2}{ }^{-}$and $\mathrm{NO}_{3}{ }^{-}$concentrations exceeded the maximum allowable concentration (MAC) in groundwater by 400, 128 and 3 times, respectively. High concentrations of nitrogen in groundwater were caused by the presence of a wide range of $\mathrm{N}$-bearing heterocyclic compounds in the tailings that were used as flotation reagents [30].

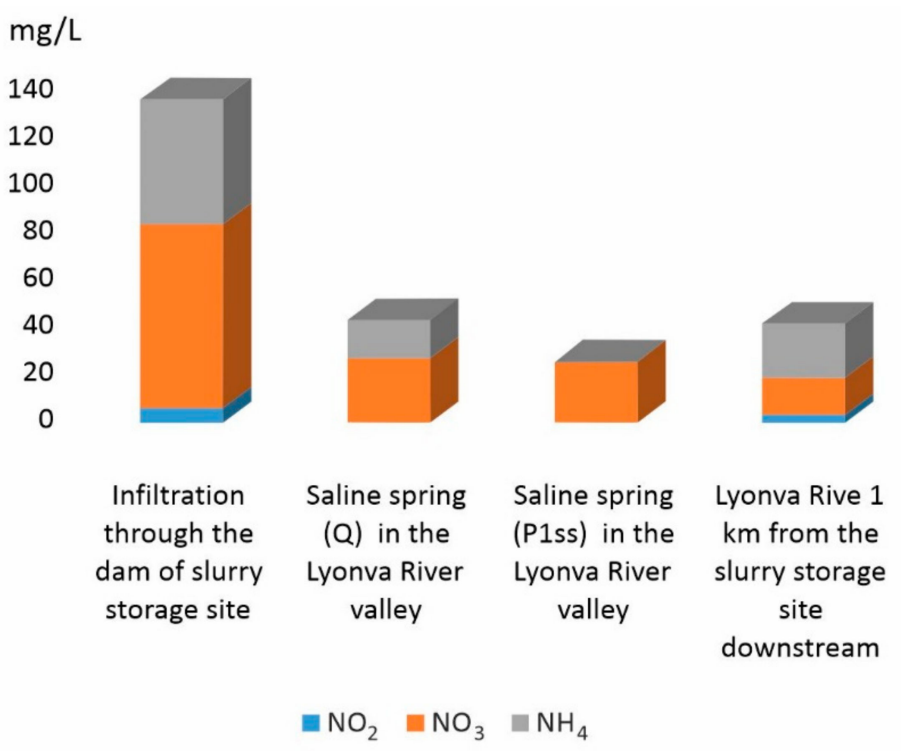

Figure 7. Concentrations of nitrogen compounds in drainage, groundwater and surface water in area effected by slurry storage site.

When saline groundwater meets confining beds, it seeps into the surface in the river valleys and pollutes the surface water (Figure 6). The streams have a $\mathrm{Ca}-\mathrm{HCO}_{3}$ water type; the salt-affected streams have $\mathrm{Na}-\mathrm{Cl}$ and $\mathrm{Ca}, \mathrm{Na}-\mathrm{Cl}$ water types. The chloride concentration in the salt-affected streams exceeds the maximum limit $\left(300 \mathrm{mg} \mathrm{L}^{-1}\right)$ recommended for the protection of freshwater life by more than 20 times. The TDS of the river water ranged from $3.4 \mathrm{~g} / \mathrm{L}$ to $12.9 \mathrm{~g} / \mathrm{L}$, and the $\mathrm{Cl}^{-}$concentration in the salt-affected streams 
was up to $34.6 \mathrm{~g} \mathrm{~L}^{-1}$. The high $\mathrm{K}$ concentration (up to $4.23 \mathrm{~g} \mathrm{~L}^{-1}$ ) is attributable to river salinisation caused by the drainage waters of potash mining [22]. The background soil in the researched area is classified as an alluvial grey humic gley soil according to the classification of soils of Russia [21]. While, according to the World reference base (WRB) for soil resources 2014 [31], the soil is called Gleyic Fluvisols (Loamic). Underground mining causes subsidence processes, karst sinkhole formation and an increase in the water table in the surrounding area. The presence of shallow groundwater of the $\mathrm{Na}-\mathrm{Cl}$ type develops waterlogging processes in the river valley which promotes soil salinity (Figure 6). The presence of dead trees in the river valley indicates that marsh forming developed relatively recently (Figure 8).
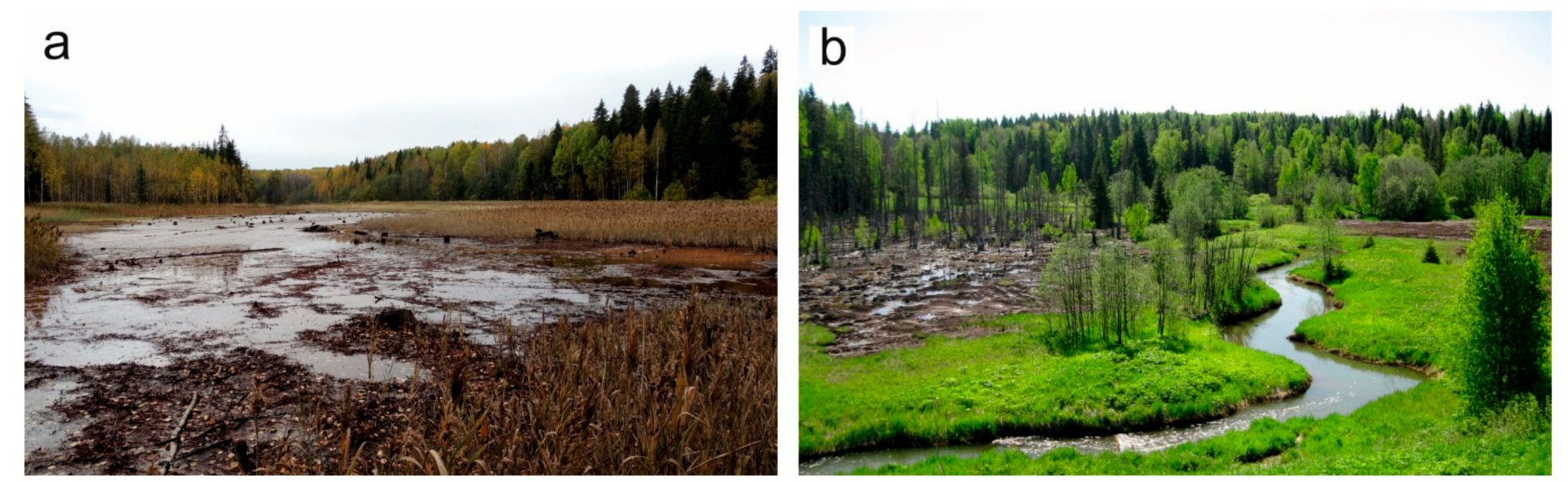

Figure 8. Different stages of ecosystem transformation to marsh: (a) a salt marsh forming after salt tailing pile construction; (b) seepage areas in the river valley with bare soils.

Two types of soils were identified in the Lyonva River valley depending on the ground water influence and according to the WRB Classification (2015) [31] (Figures 5 and 6): (1) Gleyic Fluvisols (Salic, Loamic, Technic) (alluvial gley humic clay chloride saline soil according classification soils of Russia); (2) Chloridic Gleyic Fluvic Solonchak (Hypersalic, Loamic, Technic) (secondary solonchak on alluvial humic cley soil sulphate-chloride gypsum-containing surface-gleyed according to classification soils of Russia).

The physicochemical properties of the investigated soils are presented in Table 2.

Gleyic Fluvisols (Salic, Loamic, Technic) consist of three horizons and are covered by vegetation, dominated by plants of the families Poáceae and Apiáceae. The top $20 \mathrm{~cm}$ was a grey-humus horizon (grey-brown coloured). It was densely intertwined with roots at a depth of $10 \mathrm{~cm}$, and the roots were rare below $10 \mathrm{~cm}$. The soil colour became darker at a depth of $14 \mathrm{~cm}$ and the soil structure was cloddy. A pale grey colour and rust-stains were observed at a depth of $18 \mathrm{~cm}$. Gleyed horizon Czg was formed at a depth of 20-70 cm. This horizon had a brown colour, rust-stains and iron-manganese nodules. An alluvial gleyed horizon Czg with blue-grey colour and rust-stains was identified at a depth of $70 \mathrm{~cm}$. Below $100 \mathrm{~cm}$, a blue-grey colour without rust-stains was observed.

The content of organic matter in the investigated soils varied from 5.4 to 5.9 , which is a typical value for natural alluvial soils [32,33]. The active $\left(\mathrm{pH}_{\mathrm{H} 2 \mathrm{O}}\right)$ and exchangeable $\left(\mathrm{pH}_{\mathrm{KCl}}\right)$ acidity of soils changed slightly with depth. Gleyic Fluvisols (Salic, Loamic, Technic) had an acid $\mathrm{pH}_{\mathrm{H} 2 \mathrm{O}}=4.16-5.18$; the hydrolytic acidity also confirms this (13.3 meq/100 g) (Table 2). The cation exchange capacity of the surface layer of Gleyic Fluvisols (Salic, Loamic, Technic) was $68.5 \mathrm{meq} / 100 \mathrm{~g}$. The content of mobile phosphates in Gleyic Fluvisols (Salic, Loamic, Technic) soil was $3.5 \mathrm{mg} / 100 \mathrm{~g}$ in layers of $3-20 \mathrm{~cm}$, the content of mobile potassium in the upper layer was $27 \mathrm{mg} / 100 \mathrm{~g}$. 
Table 2. Physicochemical properties of soils.

\begin{tabular}{|c|c|c|c|c|c|c|c|c|c|c|c|c|c|}
\hline Soil Type & Horizon & $\begin{array}{l}\text { Layer } \\
\mathrm{cm}\end{array}$ & $\underset{\%}{\text { Corg }}$ & $\begin{array}{c}\mathrm{H}_{2} \mathrm{~S} \\
\mathrm{mg} / \mathrm{kg}\end{array}$ & $\mathrm{pH}-\mathrm{H}_{2} \mathrm{O}$ & $\mathrm{pH}-\mathrm{KCl}$ & CEC & $\begin{array}{c}\text { Sum of } \\
\text { Exchangeble } \\
\text { Bases } \\
\text { meq/100 g }\end{array}$ & $\begin{array}{l}\text { Hydrolytic } \\
\text { Acidity }\end{array}$ & $\begin{array}{c}\mathrm{P}_{2} \mathrm{O}_{5} \\
\mathrm{HCl} \\
\mathrm{mg} / 100 \mathrm{~g}\end{array}$ & $\begin{array}{c}\mathrm{K}-\mathrm{HCl} \\
\mathrm{mg} / 100 \mathrm{~g}\end{array}$ & $\begin{array}{c}\text { Amount of } \\
\text { Toxic Salts } \\
\%\end{array}$ & SAR \\
\hline \multirow{6}{*}{$\begin{array}{l}\text { Gleyic Fluvisols (Salic, } \\
\text { Loamic, Technic) }\end{array}$} & \multirow{3}{*}{$\mathrm{Az}$} & $3-20$ & 5.4 & $<0.32$ & 4.69 & 5.42 & 82.7 & 69.4 & 13.3 & 3.5 & 27 & 0.4 & 1.5 \\
\hline & & $20-30$ & - & $<0.32$ & 4.47 & 4.48 & - & - & - & - & - & 0.2 & 1.6 \\
\hline & & $32-42$ & - & - & 5 & 4.78 & - & - & - & - & - & 0.25 & 1.9 \\
\hline & \multirow{3}{*}{ Czg } & $50-60$ & - & - & 4.16 & 3.97 & - & - & - & - & - & 0.45 & 1.6 \\
\hline & & $70-80$ & - & - & 4.68 & 4.72 & - & - & - & - & - & 1.3 & 2.1 \\
\hline & & 95-105 & - & - & 5.18 & 5.22 & - & - & - & - & - & 1 & 1.9 \\
\hline \multirow{2}{*}{$\begin{array}{l}\text { Solonchak (Hypersalic, } \\
\text { Loamic, Technic) }\end{array}$} & & $3-15$ & 5.8 & 17 & 6.75 & 6.7 & 37.3 & 36.1 & 1.1 & 0.8 & 150 & 17.1 & 36.3 \\
\hline & Czng & $15-70$ & - & 14.2 & 5.8 & 5.8 & - & - & - & - & - & 9.3 & 10.2 \\
\hline
\end{tabular}

- not observed. SAR: sodium adsorption ratio. 
Gleyic Fluvisols (Salic, Loamic, Technic) had a calcium-sodium chloride type of soil salinisation. The top soil horizon $(5-15 \mathrm{~cm})$ had high ion concentrations in the soil-water extract (mg/kg): $\mathrm{Cl}^{-}-330 ; \mathrm{Na}^{+}-39.1 ; \mathrm{K}^{+}-7.8$ (Figure 9a). However, at a depth of $50 \mathrm{~cm}$, the ion content increased and in the lower soil horizon-at a depth of $70 \mathrm{~cm}-$ contents of $\mathrm{Cl}^{-}$and $\mathrm{Na}^{+}$reached 902 and $108 \mathrm{mg} / \mathrm{kg}$, respectively. The highest ion concentrations (excluding $\mathrm{HCO}_{3}{ }^{-}$) were detected in the low horizon at a depth of $70-80 \mathrm{~cm}$.
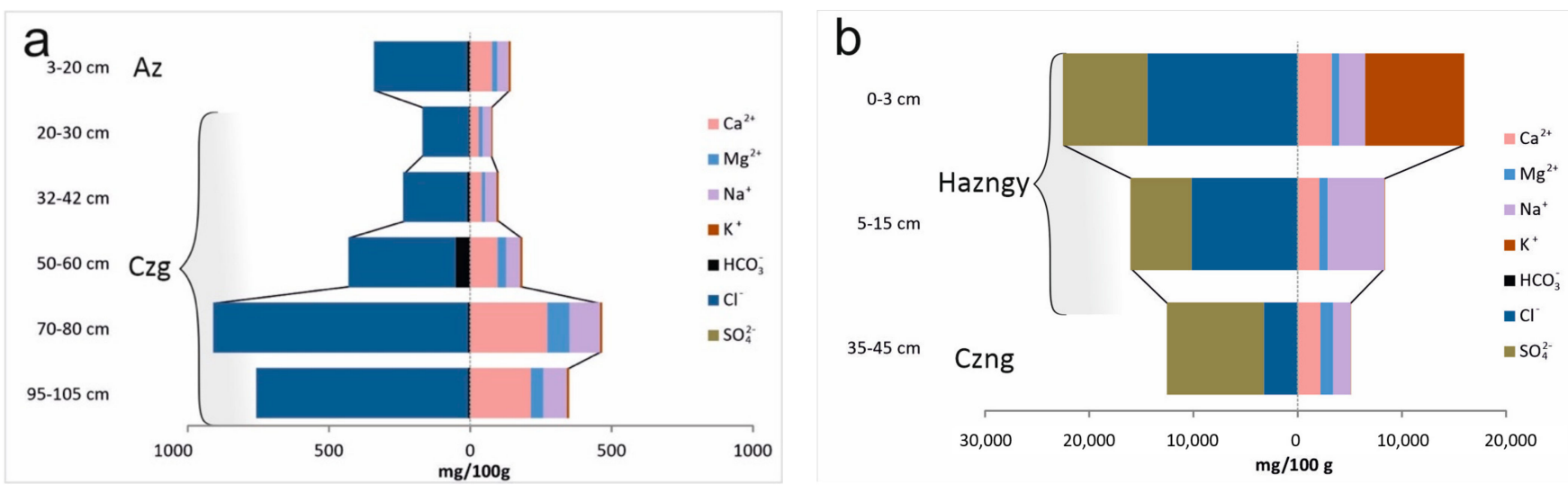

Figure 9. The content of water-soluble ions in: (a) Gleyic Fluvisols (Salic, Loamic, Technic); (b) Chloridic Gleyic Fluvic Solonchak (Hypersalic, Loamic, Technic).

Chloridic Gleyic Fluvic Solonchak (Hypersalic, Loamic, Technic) was slightly acidic $\left(\mathrm{pH}_{\mathrm{H} 2 \mathrm{O}}=5.8-6.75\right)($ Table 2). The surface layers of Chloridic Gleyic Fluvic Solonchak (Hypersalic, Loamic, Technic) were characterised by a high cation exchange capacity and amounted to $71-37 \mathrm{meq} / 100 \mathrm{~g}$, which is associated with an organic matter content of $5.9 \%$; the sum of exchangeable bases indicates the saturation of soils with bases. The content of mobile phosphates in Chloridic Gleyic Fluvic Solonchak (Hypersalic, Loamic, Technic) was $3.5 \mathrm{mg} / 100 \mathrm{~g}$ the $0-3 \mathrm{~cm}$ layer, and $0.8 \mathrm{mg} / 100 \mathrm{~g}$ in the $3-15 \mathrm{~cm}$ layer. The content of mobile potassium in the upper layer of Chloridic Gleyic Fluvic Solonchak (Hypersalic, Loamic, Technic) was $550-150 \mathrm{mg} / 100 \mathrm{~g}$ which is five to 20 times higher than that in Gleyic Fluvisols (Salic, Loamic, Technic), which is associated with salinisation of the soil by groundwater. In Chloridic Gleyic Fluvic Solonchak (Hypersalic, Loamic, Technic), the SAR exceeds 13, which indicates a high percentage of exchangeable sodium (Table 2).

Chloridic Gleyic Fluvic Solonchak (Hypersalic, Loamic, Technic) was characterised by a sulphate-chloride calcium-sodium type of soil salinisation. The content of water-soluble ions in the Chloridic Gleyic Fluvic Solonchak (Hypersalic, Loamic, Technic) significantly exceeded the amount in the Gleyic Fluvisols (Salic, Loamic). The top layer of Chloridic Gleyic Fluvic Solonchak (Hypersalic, Loamic, Technic) $(\sim 3 \mathrm{~cm})$ was an iron-bearing crust without any vegetation. A salt-sulphide horizon Hazngy $(3-15 \mathrm{~cm})$ consisted of black gel-like phases with high contents of plant residues, we noted a gypsum content of $8.5 \%$. A gley loam horizon Czng $(15-70 \mathrm{~cm})$ had a grey colour with rust-stains. In the $0-3 \mathrm{~cm}$ layer, the maximum content of water-soluble ions was observed in the top layer of the soil (mg/100g): $\mathrm{Cl}^{-}-1400, \mathrm{~K}^{+}-9500, \mathrm{Na}^{+}-2500$ (Figure $9 \mathrm{~b}$ ). These extremely high ion concentrations are associated with salt water-logging. The soil-water extract had much higher concentrations of $\mathrm{Cl}^{-}, \mathrm{Na}^{+}$and $\mathrm{K}^{+}$than the background soil (e.g., (mg/100 g) $\mathrm{Cl}^{-} 0.6-2.5$, $\left.\mathrm{K}^{+}-1.48, \mathrm{Na}^{+}-2.0\right)$ [15]. The maximum content of water-soluble ions decreased slightly with depth (Figure $9 \mathrm{~b}$ ). The sum of toxic salts was equal to $26 \%$, which corresponded to a very high degree [34] of soil salinity (Table 2).

The insoluble part of the samples, collected from the uppermost horizon $(0-3 \mathrm{~cm}$ depth), had the highest content of iron minerals of amorphous form (up to $84.9 \%$ ) and Fe-bearing plant residues (up to $86.8 \%$ ) (Table 3, Figure 10). 
Table 3. Mineralogical composition of soil of Chloridic Gleyic Fluvic Solonchak (Hypersalic, Loamic, Technic) in seepage areas in the Lyonva River Valley (\%).

\begin{tabular}{|c|c|c|c|c|c|c|c|c|c|}
\hline $\begin{array}{l}\text { Depth of } \\
\text { Sample }\end{array}$ & $\begin{array}{c}\text { No } \\
\text { Sample }\end{array}$ & Quartz & $\begin{array}{c}\text { Fe-Bearing } \\
\text { Plant Residues }\end{array}$ & $\begin{array}{c}\text { Iron } \\
\text { Minerals }\end{array}$ & Hydrogothite & Hematite & $\begin{array}{l}\text { Oxides } \\
\text { of Mn }\end{array}$ & $\begin{array}{l}\text { Organic } \\
\text { Residues }\end{array}$ & $\begin{array}{c}\text { Other } \\
\text { Minerals }\end{array}$ \\
\hline \multirow{4}{*}{$0-3 \mathrm{~cm}$} & 4.1 & 0.1 & 10.0 & 84.9 & - & - & - & - & 5.0 \\
\hline & 6.1 & 2.5 & 86.8 & 6.0 & - & - & - & - & 4.7 \\
\hline & 8.1 & 1.0 & 20.0 & 73.9 & - & - & - & - & 5.1 \\
\hline & 11.1 & 0.5 & 30.0 & - & 68.2 & - & - & - & 1.3 \\
\hline \multirow{3}{*}{$3-30 \mathrm{~cm}$} & 4.2 & 57.6 & 9.0 & 25.0 & - & - & - & - & 8.4 \\
\hline & 6.2 & 78.2 & 3.0 & 8.0 & - & - & 0.3 & - & 10.5 \\
\hline & 8.2 & 5.0 & 5.0 & - & 84.8 & - & - & - & 5.2 \\
\hline
\end{tabular}

- not observed.
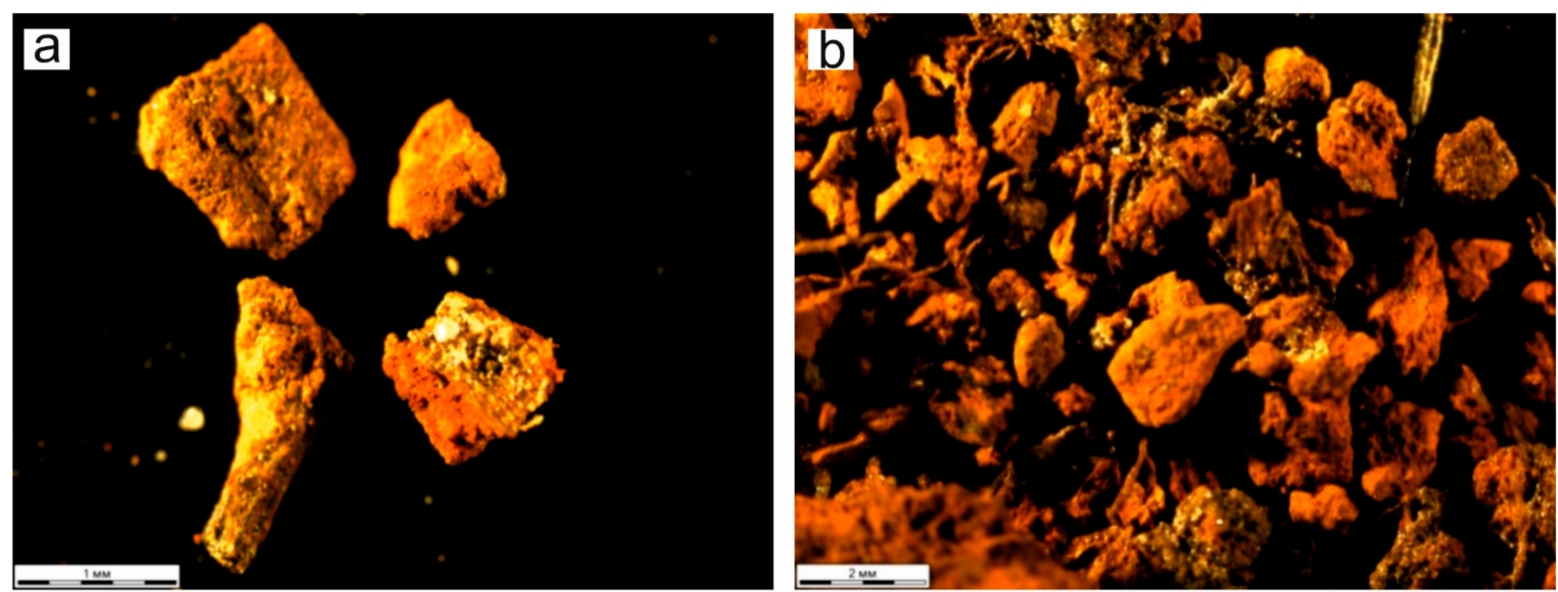

Figure 10. Images of iron-bearing phases: (a) Fe-bearing plant residues; (b) Fe-bearing minerals.

The scanning electron microscope images of the reddish-yellow iron-rich precipitates on the surface of upper soil horizon showed cubic halite crystals, flaky particles, a crust of iron oxides-hydroxides (Figure 11) and spongy residues. The spongy siliceous residues are remains of diatoms and are enriched in $\mathrm{Ca}, \mathrm{Fe}, \mathrm{Cl}, \mathrm{K}, \mathrm{Na}, \mathrm{S}$, and $\mathrm{P}$ (Figure 12).

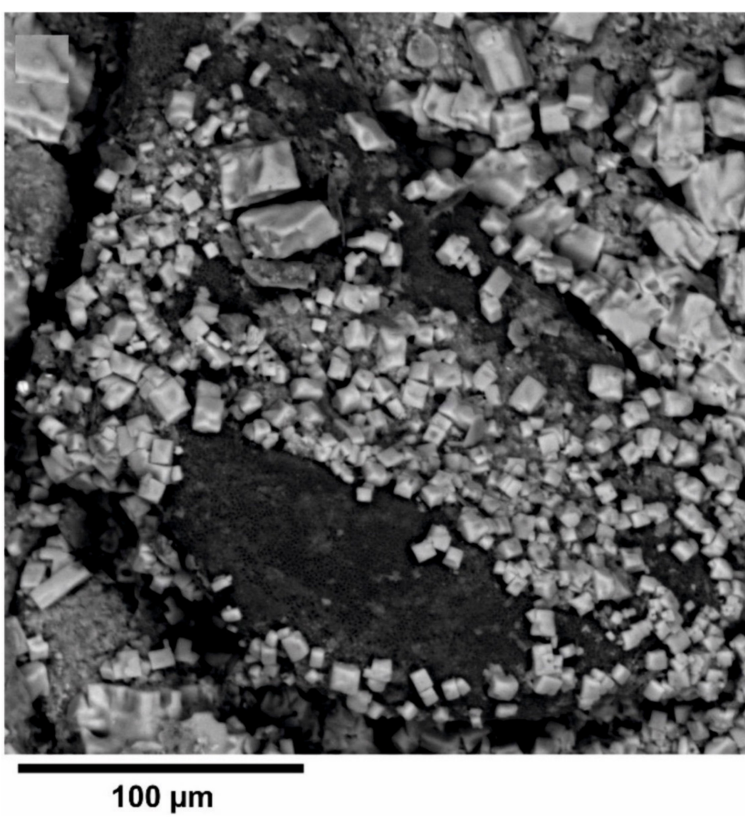

Figure 11. Upper soil horizon (0-3 cm depth) with reddish-yellow iron-rich precipitates and cubic halite crystals on the surface of soil. 

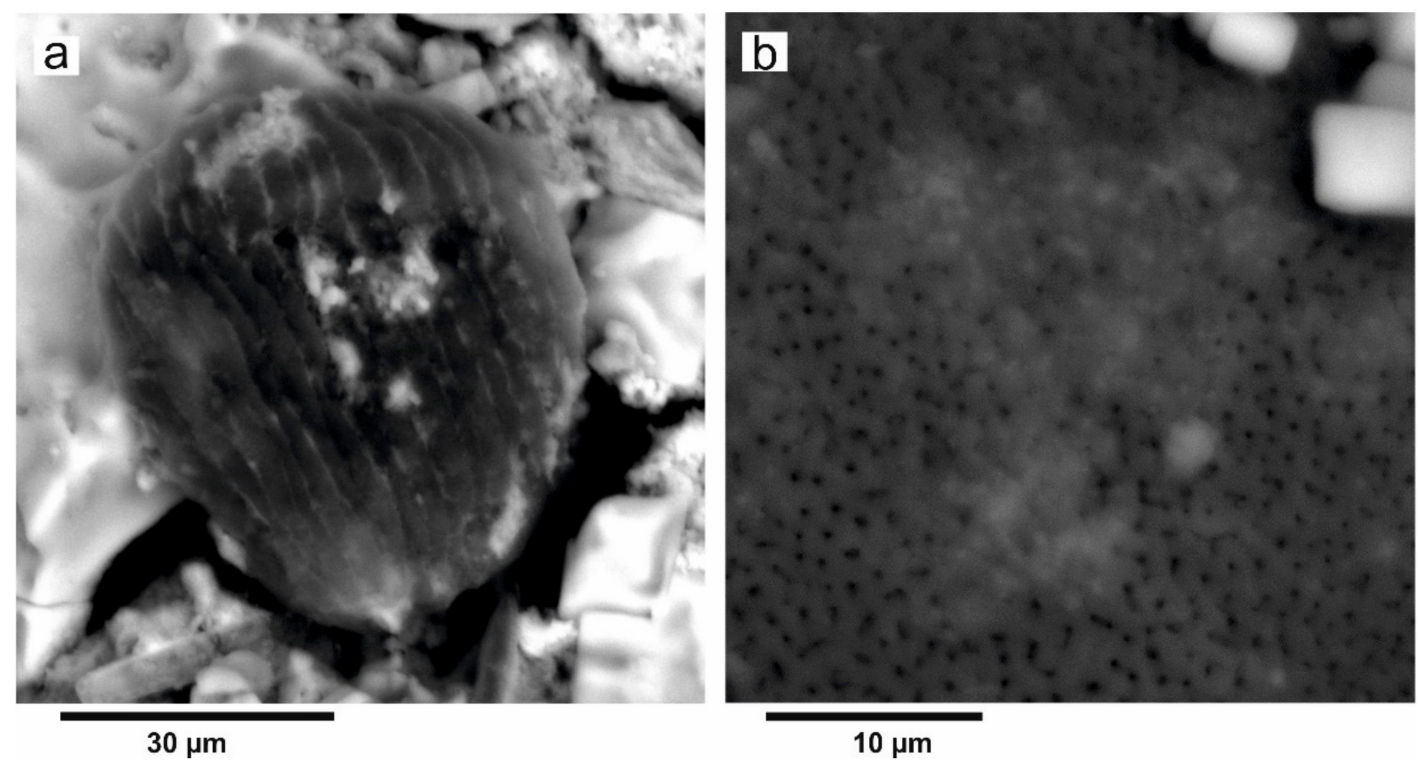

Figure 12. Upper soil horizon (0-3 cm depth) with organic material: (a) layered organic formation; (b) spongy residue.

The lower soil horizon (3-30 cm depth) consists of black gel-like phases with a high content of plant residues. The high concentrations of sulphate in the saline waters (Table 2) and microbiological activities led to hydrogen sulphide formation in this horizon (Figure 5). Content of $\mathrm{H}_{2} \mathrm{~S}$ varied from $17 \mathrm{mg} / \mathrm{kg}$, Eh decreased up to -156--197 which corresponded to a reducible condition. Siliceous remains of diatoms, halite, plant residues and ironbearing phases were found in samples (Figure 13).

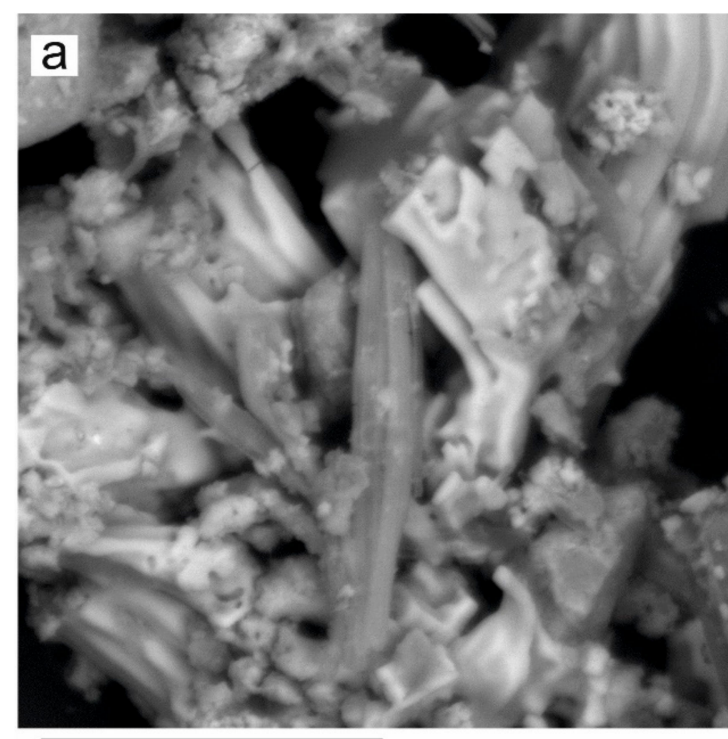

$70 \mu \mathrm{m}$

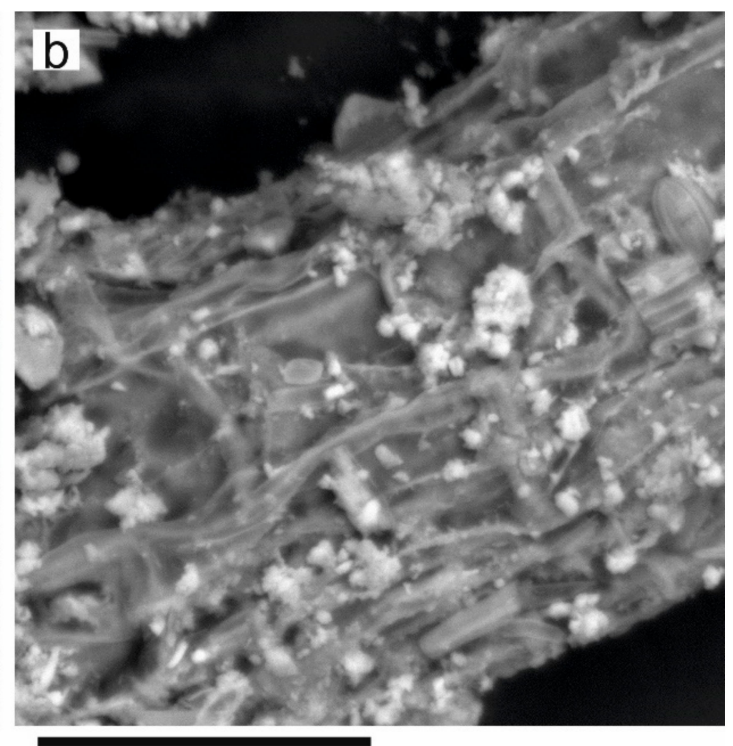

$70 \mu \mathrm{m}$

Figure 13. Lower soil horizon (3-15 cm depth) black gel-like phases, hydrotroillite horizon: (a) siliceous remains of diatoms, halite, iron-bearing formation; (b) plant residue covered by siliceous remains of diatoms and iron-bearing phases.

The inflow of sulphate ions with seepage drainages into groundwater and river waters promotes sulphate reduction in the anaerobic settings of soils due to the activity of sulphatereducing bacteria. Desulphurisation and the formation of $\mathrm{H}_{2} \mathrm{~S}$ is a common process under natural conditions, for example, in sulphate water bodies of steppes and deserts [11], under the conditions of saline groundwater inflow [13], along the seashore [35], along the low swampy shores of Sakhalin Island in conditions of flooding by sea waters [36]. 
The $\mathrm{H}_{2} \mathrm{~S}$ released during sulphate reduction interacts with highly mobile iron species, forming an insoluble aqueous iron hydrate-hydrotroillite $\left(\mathrm{FeS} \cdot \mathrm{nH}_{2} \mathrm{O}\right)$. This mineral forms a black gel-like soil layer. Hydrotroillite is an unstable mineral and various geochemical settings are required for its formation: anaerobic settings, presence of organic matter, iron and sulphates [14].

The insoluble part of the samples contained up to $84 \%$ hydrogoethite (Table 3 ), which was the result of iron oxidation during sample preparation. We suggest that hydrotroillite was the predominant iron-bearing mineral in this horizon. Other iron minerals (hematite and magnetite) were also identified in the samples (Table 3).

Carbonaceous and organic residues, manganese oxides and gypsum were identified in the soil profile of Chloridic Gleyic Fluvic Solonchak (Hypersalic, Loamic, Technic). Gypsum formed during the interaction of calcium in the parent rocks and sulphate in highly mineralised waters. The biogenic type of gypsum formation may be associated with the activity of thionic bacteria [37].

The observations during 2013-2016 showed that the hydrotroillite horizon is extremely unstable and its thickness varied depending on the amount of precipitation and the groundwater level. The underlying horizon at the depth of $40-80 \mathrm{~cm}$ had a gley condition. The low organic content limited the growth of sulphate-reducing bacteria and hydrogen sulphide was not formed.

The sources of iron in the soils and bottom sediments include the iron-enriched Sheshma sediments (P1ss) speckled rocks, slurry material and halite wastes and soil minerals of alluvial gley soils.

The main source of Fe and other metals in potash rocks is a continental runoff water [38]. Hypergenic destruction of carnallite and sylvinite rocks leads to the concentration of these elements in the salt layer [39]. In the water-soluble part of the salts, the Fe content is $\mathrm{n} \times 10^{-5} \%$ [38]. Fe (III) was found as $\mathrm{FeCl}_{3}$ and as an isomorphic replacement of $\mathrm{Mg}$ in carnallite; Fe (II) was mainly found in the form of rinneite minerals, less often in douglasite, widely represented in the German Zechstein in the lower Cambrian of Siberia, and in the Khimiset deposit (Morocco) [38].

At many deposits of potassium salts, gypsum-clay caps were uncovered and composed of dark grey brecciated clays with interlayers, lenses and inclusions of transparent and brownish-red grains of gypsum films, lenses and streaks of red, reddish-orange, orangeyellow ferruginous substances, which were named hematite layers. They were formed as a result of salt rock destruction [40]. The hematite layers, with thicknesses from a few millimetres to 5-25 cm, were formed at the Verkhnekamskoe potash deposit [39].

Iron-bearing minerals were concentrated in waste as a result of the enrichment of potash ore. In the halite waste of the Verkhnekamskoe potash deposit, the iron content varied from 380 to $990 \mathrm{mg} / \mathrm{kg}$, and in the clay-saline sludge-from 1450 to $4200 \mathrm{mg} / \mathrm{kg}$ [17]. In clay minerals of halite waste, the iron content can reach $38.7 \mathrm{wt} . \%$ and in the material of sludge-from 2.9 to $6.8 \mathrm{wt}$.\% [17]. The pyrite content ranges from 1.3 to $1.8 \%$ [15].

Soils are a source of iron, for example, Fe (II) is oxidised with the formation of hydrogetite, goethite, hematite and other Fe-bearing phases in Taiga landscapes under the oxidizable conditions of the upper soil horizons [41,42]. In the alluvial soils of the floodplains of the Perm Krai, the main Fe-bearing minerals are goethite and Mn-feroxyhyte, with the total $\mathrm{Fe}_{2} \mathrm{O}_{3}$ content reaching 62 wt.\% [33].

The Fe release from the bottom sediment and soil might be caused by an increase in the $\mathrm{NaCl}$ content [43], which was found along with an increase in the $\mathrm{NaCl}$ content in water, the Fe (II) concentration increased in the pore water of bottom sediments. Saline drainage and saline groundwater more active than fresh groundwater at leaching Fe from the iron-rich speckled aquifer, slurry material, and soil minerals.

\section{Conclusions}

The formation of Gleyic Fluvisols (Salic, Loamic, Technic) and Chloridic Gleyic Fluvic Solonchak (Hypersalic, Loamic, Technic) in the territory of the Verkhnekamskoe potash 
deposit was determined by the close occurrence of $\mathrm{Cl}-\mathrm{Na}$ groundwater with a high content of sulphates. As a result of the interaction between technogenic brines and parental rocks and soils, the contents of sulphate and iron increased, leading to the formation of sulphide salt marshes with the deposition of Fe-bearing minerals on the surface and hydrotroillite horizon under anaerobic conditions. The sources of iron in the soils include speckled rocks, slurry material and soil minerals. The intensity of technogenic salinisation and subsidence of the Earth's surface in mining areas contribute to the formation of large areas of soil salinisation in valley landscapes.

Author Contributions: Conceptualization and methodology, E.K.; investigation, E.K., A.B., L.N., N.M., validation, A.B.; formal analysis, N.M.; resources, L.N.; data curation, N.M.; writing-original draft preparation, E.K.; writing-review and editing, A.B.; funding acquisition, E.K. All authors have read and agreed to the published version of the manuscript.

Funding: This work was supported by the Ministry of Science and Higher Education of the Russian Federation (No 2019-0858) and The program of activities of the world-class research and education center "Rational Subsoil Use" for 2019-2024 with the financial support of the Science and Higher Education of the Russian Federation (order of the Government of the Russian Federation of 30 April 2019 No. 537).

Acknowledgments: The authors wish to thank Evgeniya Yakovleva for providing assistance in working on the text, Natalya Poroshina for conducting chemical analyses and Aleksey Denisov for organising of and assistance in field work.

Conflicts of Interest: The authors declare no conflict of interest.

\section{References}

1. Arle, J.; Wagner, F. Effect of anthropogenic salinisation on the ecological status of macroinvertebrate assemblages in the Werra River (Thuringia, Germany). Hydrobiologia 2013, 701, 129-148. [CrossRef]

2. Baure, M.; Eichinger, L.; Elsass, P.; Kloppmann, W.; Wirsing, G. Isotopic and hydrochemical studies of groundwater flow and salinity in the Southern Rhine Graden. Int. J. Earth Sci. 2005, 94, 565-579. [CrossRef]

3. Bel'tyukov, G.V. Main sources of contamination of groundwater and surface waters in the area of the Verkhnekamskoe potash deposit. Vestn. Permsk. Univ. 1996, 4, 128-140. (In Russian)

4. Lyubimova, T.P.; Lepikhin, A.P.; Parshakova, Y.N.; Tsiberkin, K.B. Numerical modeling of liquid-waste infiltration from storage facilities into surrounding groundwater and surface-water bodies. J. Appl. Mech. Tech. Phys. 2016, 57, 1208-1216. [CrossRef]

5. Liu, Y.; Lekhov, A.V. Modeling changes in permeability characteristics of gypsified rocks accompanying brine flow. Water Resour. 2013, 40, 776-782. [CrossRef]

6. Lucas, Y.; Schmitt, A.D.; Chabaux, F.; Clément, A.; Fritz, B.; Elsass, P.; Durand, S. Geochemical tracing and hydrogeochemical modelling of water-rock interactions during salinization of alluvial groundwater (Upper Rhine Valley, France). Appl. Geochem. 2010, 25, 1644-1663. [CrossRef]

7. Hulisz, P.; Piernik, A. Soil affected by soda industry in Inowrocław. In Technogenic Soils of Poland; Charzyński, P., Hulisz, P., Bednarek, R.M., Eds.; Polish Society of Soil Science: Torun, Poland, 2013; pp. 125-140. ISBN 978-83-934096-1-7.

8. Sommer, V.; Karsten, U.; Glaser, K. Halophilic algal communities in biological soil crust isolated from potash tailings pile areas. Front. Ecol. Evol. 2020, 8. [CrossRef]

9. Kolpashnikov, G.A.; Klement'ev, V.P.; Eremenko, Y.P. Processes of soil and groundwater salinization by solid wastes generated by Soligorsk potash mining operations. Doklad AN BSSR 1979, 14, 443-446. (In Russian)

10. Khomich, V.S.; Zhumar, P.V.; Korobeynikov, B.I.; Tishchikov, G.M. Degradation of the Natural Environment in the Impact Zones of Potash Production; Natural Environment of Belarus: Minsk, Belarus, 2002; pp. 332-347.

11. Perel'man, A.I.; Kasimov, N.S. Geohimiya Landshafta (Geochemistry of Landscape); Astrea-2000: Moscow, Russia, 1999; 763p, ISBN 5759400770. (In Russian)

12. Fitzpatrick, R.; Degens, B.; Baker, A.; Raven, M.; Shand, P.; Smith, M.; Rogers, S.; George, R. Avon Basin, WA Wheatbelt: Acid Sulfate Soils and Salt Efflorescences in Open Drains and Receiving Environments. In Inland Acid Sulfate Soil Systems Across Australia; Fitzpatrick, R., Shand, P., Eds.; CRC LEME Open File Report No. 249. (Thematic Volume); CRC LEME: Perth, Australia, 2008; pp. 189-204. ISBN 9780643096257.

13. Salama, R.B.; Otto, C.J.; Fitzpatrick, R.W. Contributions of groundwater conditions to soil and water salinization. J. Hydrogeol. 1999, 7, 46-64. [CrossRef]

14. Khomich, V.S. Sulphide neoplasms in soil as a result of the interaction of natural and technogenic factors. Rep. Acad. Sci. BSSR 1985, XXIX, 267-270.

15. Khayrulina, E.; Maksimovich, N. Influence of drainage with high contents of water-soluble salts on the environment in the Verkhnekamskoe potash deposit, Russia. Mine Water Environ. 2018. [CrossRef] 
16. Mineral Resources of the Perm Region. Encyclopedia; Kudrjashov, A.I., Osovetsky, B.M., Eds.; Mining Institute Ural Branch of the Russian Academy of Sciences: Perm, Russia, 2006; p. 207. ISBN 5-88187-288-6. (In Russian)

17. Kudryashov, A.I. Verkhnekamskoe Salt Deposit; Mining institute of Ural Branch of RAS: Perm, Russia, 2001; ISBN 5-89095-041-X. (In Russian)

18. Fetisova, N.F.; Fetisov, V.V.; Maio, M.D.; Zekster, I.S. Groundwater vulnerability assessment based on calculation of chloride travel time through the unsaturated zone on the area of the Upper Kama potassium salt deposit. Environ. Earth Sci. 2016, 75, 681. [CrossRef]

19. Bachurin, B.A.; Baboshko, A.U. Ecological and geochemical characteristics of the potash production wastes. Gorn. Žurnal 2008, 10, 88-91. (In Russian)

20. Andreichuk, V.; Eraso, A.; Domínguez, M.C. A large sinkhole in the Verchnekamsky potash basin in the Urals. Mine Water Environ. 2000, 19, 2-18. [CrossRef]

21. Shishov, L.L.; Tonkonogov, V.D.; Lebedeva, I.I.; Gerasimova, M.I. Classification and Diagnosis of Soils of Russia. Oykumena: Smolensk, Russia, 2004; ISBN 5-86921-026-7. (In Russian)

22. Khayrulina, E. Aspects of the environmental monitoring on the territory of Verkhnekamskoye Potash Deposit (Russia). Mining Meets Water-Conflicts and Solutions. In Proceedings of the IMWA2016 Annual Conference, Leipzig, Germany, 11-15 July 2016; pp. 383-387, ISBN 9781510827141.

23. GOST 26423-85 Soils. Methods for Determination of Specific Electric Conductivity, pH and Solid Residue of Water Extract; Standartinform: Moscow, Russia, 1985.

24. Vorobyova, L.F. Theory and Practice Chemical Analysis of Soils; GEOS: Moscow, Russia, 2006; ISBN 5-89118-344-7. (In Russian)

25. Mineev, V.G. Praktikum Po Agrohimii (Workshop on Agricultural Chemistry); Moscow University Press: Moscow, Russia, 2001; ISBN 5-211-04265-4. (In Russian)

26. SanPiN 42-128-4433-87. Sanitary Standards for Permissible Concentrations of Chemicals in the Soil; Printing House of the USSR Ministry of Health: Moscow, Russia, 1987. (In Russian)

27. Myakina, N.B.; Arinushkina, E.V. Methodical Manual to Read the Results of Chemical Analyzes; Moscow University Press: Moscow, Russia, 1979. (In Russian)

28. Mamontov, V.G.; Gladkov, A.A.; Kuzelev, M.M. Practical Guide to Soil Chemistry; Textbook; Mamontov, V.G., Gladkov, A.A., Kuzelev, M.M., Eds.; Publishing house of the Russian State Agrarian University-Moscow Timiryazev Agricultural Academy: Moscow, Russia, 2012.

29. van Reeuwijk, L.P. Procedures for Soil Analysis, 7th ed.; Technical Report 9; ISRIC—World Soil Information: Wageningen, The Netherlands, 2002.

30. Bachurin, B.A.; Smetannikov, A.Y.; Khokhryakova, E.S. Environmental and geochemical assessment of processing products of clay-salt slurries generated by potash mining operations. In Sovremennye Problemy Nauki I Obrazovaniya [Modern Problems of Science and Education]; 2014; Volume 6. Available online: http://www.science-education.ru/ru/article/view?id=15442 (accessed on 20 September 2017). (In Russian)

31. FAO. World Reference Base for Soil Resources 2014, Update 2015 International Soil Classification System for Naming Soils and Creating Legends for Soil Maps; World Soil Resources Reports No. 106; FAO: Rome, Italy, 2015; 203p.

32. Troeh, F.R.; Thompson, L.M. Soils and Soil Fertility, 6th ed.; Blackwell Publish: Ames, IA, USA, 2005; ISBN 978-0-813-80955-7.

33. Vasiliev, A.A.; Romanova, A.V. Iron and Heavy Metals in Alluvial Soils of the Middle Pre Ural Region; Publishing Printing Center "Prokrost": Perm, Russia, 2014; ISBN 978-5-94279-210-7. (In Russian)

34. Bazilevich, N.I.; Pankova, E.I. Metodicheskie Ukazaniya po Uchetu Zasolyonnyih Pochv [Methodological Instructions for the Calculation of Saline Soils]; Giprovodkhoz M: Moscow, Russia, 1968. (In Russian)

35. Hulisz, P.; Kwasowski, W.; Pracz, J.; Malinowski, R. Coastal acid sulphate soils in Poland: A review. Soil Sci. Annu. 2017, 68, 46-54. [CrossRef]

36. Poberezhnaya, T.M. Landscape-geochemical studies in Sakhalin. Vestnik 2006, 1, 109-114.

37. Buyanovskiy, G.A. The Influence of Biological Processes on the Mobile Components of the Mineral Part of the Kura-Aras Lowland Soils. Ph.D. Thesis, Academy of Sciences of the Azerbaijan SSR: Baku, Azerbaijan, 1972.

38. Popov, V.S.; Osichkina, R.G.; Tillyakhodzhaev, K.N. On the geochemistry of iron, manganese, copper in the process of halogenesis. In Lithofacies and Geochemical Problems of Salt Accumulation; Nauka: Moscow, Russia, 1985; pp. 3-12.

39. Bel'tyukov, G.V. Karst i Gipergennye Processy (Karst and Hypergene Processes in Evaporates). Ph.D. Thesis, Perm State University, Perm, Russia, 2000; 346p.

40. Migunov, L.V. Infiltration Mineral Zonation of Suprasalt Strata; Nauka: Saint Petersburg, Russia, 1994. (In Russian)

41. Vodyanitsky, Y.N.; Vasiliev, A.A.; Kozheva, A.V.; Sataev, E.F. Features of the iron behaviour in soddy-podzolic and alluvial gleyed soils of the Middle Urals. Pochvovedenie 2006, 4, 396-409, ISSN 0032-180X.

42. Glazovskaya, M.A. Geochemistry of Natural and Technogenic Landscapes; Faculty of Geography, Moscow State University: Moscow, Russia, 2007; ISBN 5-85941-225-8.

43. Baldwin, D.S.; Rees, G.N.; Mitchell, A.M.; Watson, G.; Williams, J. The short-term effects of salinization on anaerobic nutrient cycling and microbial community structure in sediment from a freshwater wetland. Wetlands 2006, 26, 455-464. [CrossRef] 